\title{
AKSESIBILITAS MEDIA SOSIAL DAKWAH MAHASISWA KOMUNIKASI PENYIARAN ISLAM (KPI) IAIN PALU
}

\section{Derwin Derwin \\ Suharto Suharto \\ Syamsuri Syamsuri}

Institut Agama Islam Negeri Palu

Email: syamsuri.palu@yahoo.com

\section{Abstract:}

This paper deals with accessibility of social media among Islamic Broadcasting Students of IAIN Palu. The question is how do students use social media to get information of Islamic preaching. The result showed that the students said that social media is highly beneficial for the development of preaching and knowledge need by the students. The reasons behind choosing social media are the easiness and quickness of access to it and time-saving. Meanwhile, social media to which students are enthusiastic include facebook, whatsapp, mailing list, blog, and so on. Facebook and whatsapp are effective enough to establish relationship to others and get access to contents of Islamic preaching, while blog is used to explore information about Islam. In seeking information of Islam, Islamic Broadcasting (KPI) students used google to carry out their task given by their lecturers and to improve their knowledge.

$$
\begin{aligned}
& \text { تناول هذا البحث في إمكانية الوصول إلى وسائل الإعلام الاجتماعية لدى طلاب الجامعة }
\end{aligned}
$$

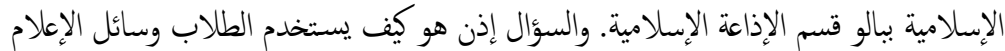

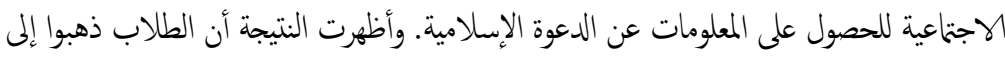

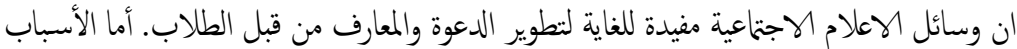

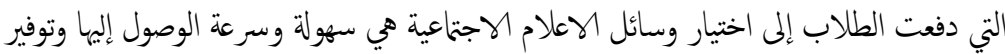

$$
\begin{aligned}
& \text { الوقت. وسائل الهلام الاجتماعية التي كان الطلاب يتحمسون هي الفيسبوك }
\end{aligned}
$$

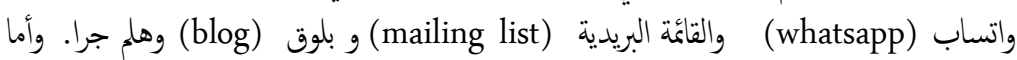

$$
\begin{aligned}
& \text { الفيسبوك و واتساب فعالة كافية لإقامة علاقة مع الآخرين والحصول على محتويات الدعوة }
\end{aligned}
$$


Derwin, Suharto, Syamsuri, Aksesibiitas Media Sosial Dakwah....

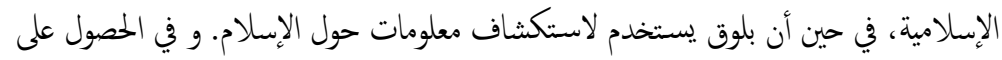

$$
\begin{aligned}
& \text { معلومات حول الإسلام، يستخدم طلاب الإذاعة الإسلامية جوجل (google) لتنفيذ مهمتهم التي لئي } \\
& \text { قدما المدرسون وتحسين معارفهم. }
\end{aligned}
$$

Kata Kunci : aksesibilitas, media sosial dakwah, mahasiswa

\section{A. Pendahuluan}

Sebelum adanya internet, masalah utama yang dihadapi pendidikan (diseluruh dunia) adalah akses kembali kepada informasi. Perpustakaan yang konvensional merupakan sumber informasi yang tidak murah. Buku-buku dan jurnal harus dibeli dengan harga mahal. Adanya internet memungkinkan mengakses kepada sumber informasi yang mulai tersedia banyak. Dengan kata lain, masalah akses semestinya bukan menjadi masalah lagi.

Sejak awal tahun 2000, teknologi informasi telah memasuki pasar utama dan dikembangkan lebih jauh menjadi apa yang disebut new wave technology. New wave technology adalah teknologi yang memungkinkan konektivitas antara individu dan kelompok. New wave technology meliputi tiga kekuatan utama: computer, teelpon genggam murah dan internet murah. Melalui teknologi ini dapat memungkinkan untuk mengekspresikan dirinya dan berkolaborasi dengan orang lain.

Internet atau media sosial merupakan salah satu produk teknologi yang dapat membantu kita meningkatkan taraf hidup melalui pendidikan. Meskipun masih banyak tantangan, seseorang dapat mengakses berbagai referensi, baik yang berupa penelitian, maupun artikel hasil kajian dari berbagai bidang. Tidak lagi secara fisik pergi ke perpustakaan dimana saja. Seseorang hanya duduk saja didepan computer (tentunya menggunakan komputer yang dilengkapi koneksi ke internet) dan 
menggunakannya. Informasi yang tersedia dapat diakses melalui internet tidak hanya ada atau terjadi disatu negara saja, tetapi juga terjadi diseluruh penjuru dunia (global world). Artinya, perkembangan yang terjadi diberbagai negara dapat dengan cepat diketahui oleh orang banyak. Demikian juga halnya dengan informasi yang menyangkut bidang pendidikan. Para akademisi merupakan satu pihak yang paling diuntungkan dengan kemunculan internet. ${ }^{1}$

Dalam kegeiatan belajar, seorang mahasiswa harus membiasakan diri dengan cara baru dalam mengikuti pendidikan. Mahasiswa harus mencari sendiri bagaimana caranya menyerap perkuliahan atau materi dari para dosen. Selain itu teknololgi Informasi sebagai perpaduan antara teknologi computer dan komunikasi membuat perubahan dalam melakukan sesuatu termasuk dalam menyampaikan dakwah yang tujuannya untuk mengajak, mendorong, (memotivasi) manusia agar berbuat kebaikan. ${ }^{2}$

Dakwah dan teknologi adalah suatu yang tidak bisa dipisahkan. Hal ini jika kita berpijak pada konsep dakwah kotemporer yang mudah diterima oleh kalangan masa kini. Teknologi bukan sesuatu yang dilarang, meskipun di zaman rasulullah belum ditemukan adanya teknologi seperti yang berkembang pesat dewasa ini. Berkembangnya dakwah perlu memperhatikan perkembangan teknologi, agar sesuatu yang dihadirkan mudah diterima, dan tidak ketinggalan zaman. Walaupun semua

${ }^{1}$ Boyd, Danah, M,. Nicole B. Ellison. 2007. Social Network Sites: Definition, History, and Scholarship.http://jcmc.indiana.edu/vol13/issue1/boyd.ellison .html (Diakses tanggal 20April 2015).

${ }^{2}$ Siregar, A. Ridwan, Panduan Perpustakaan Universitas (Medan: Perpustakaan USU, 2001), h. 71 
Derwin, Suharto, Syamsuri, Aksesibiitas Media Sosial Dakwah....

teknologi komunikasi dewasa ini bersifat positif, ada kelebihan dan kekurangan bagi umat manusia. Dengan adanya teknologi Informasi dapat dimanfaatkan sebagai media dakwah Islam. Tidak dipungkiri bahwa kemajuan teknologi itu ibarat pisau bermata dua, disatu sisi untuk memudahkan pakerjaan dan disisi lain dapat mencelakai orang lain. Karena memang kemajuan itu sangat tergantung pada dan ditangan siapa, ketika berada ditangan orang baik maka baiklah manfaatnya. Sebaliknya, jika berada ditangan orang jahat maka jahatlah dampak yang dihasilkan. Maka penggunaannyalah yang menetukan kearah mana ia dipergunakan, baik atau buruk tergantung ditangan penggunanya. Maka dari itu sebagai juru dakwah dituntut piawai menggunakan dan memanfaatkan hasil kemajuan teknologi informasi, salah satunya yaitu melalui jejaring social, baik itu facebook,twitter, maupun media social lainnya.

Pengguna media sosial yang sangat banyak ini terutama mayoritas dari kanca pemuda, membuat social media cukup alternatif untuk digunakan sebagai sarana media dakwah saat ini.Maka, tak sedikit dari para aktivis dakwah memanfaatkan media social ini. Adapun media yang paling sederhana yang digunakan beberapa penggunanya ialah facebook, dikarenakan facebook mempunyai desain minimalis tapi kaya akan fitur dan pendukung, selain itu gratis dan mudah digunakan. ${ }^{3}$

Di era internet saat ini, media jejaring sosial telah menciptakan ruang publik (public space) baru, bahkan lebih jauh dari itu, sebuah lingkungan publik (public sphere) baru bagi masyarakat maupun

${ }^{3}$ Neysya-jatidiri.blogspot.com/http://facebook-sebagai-media-dakwah.html diakses pada tanggal 28 april 2015 jam 10.04 
mahasiswa. ${ }^{4}$ Apa yang membuat para mahasiswa ini begitu gandrung dengan media jejaring social ? Salah satu teori yang bisa digunakan untuk mengkaji fenomena tersebut adalah :

"TeoriUses and Gratification, yaitu teori komunikasi yang menyatakan bahwa manusia secara aktif mencari media tertentu dan konten tertentu untuk menghasilkan kepuasan tertentu (West \& Turner dalam Alvina 2010). Berada dalam komunitas jejaring sosial membuat penggunanya merasa senang dan senantiasa ingin membuka situs-situs jejaring sosial tersebut" ${ }^{5}$

Jejaring sosial selain dapat dimanfaatkan sebagai media dakwah, jejaring social juga sebagai media hiburan yang murah meriah disaat mahasiswa lelah dengan tugas-tugas yang menumpuk. Pesatnya perkembangan kuantitas pengguna jejaring social juga turut meningkatkan nilai manfaat dari internet itu sendiri.Namun sayangnya masih banyak dari pengguna internet yang belum memanfaatkan internet dalam mendukung pendidikan mereka, sebagai salah satu layanan temu balik informasi.

Dilatar belakangi pemikiran tersebut, penulis berkeinginan untuk mengetahui lebih jauh tentang sejauh mana mahasiswa Program Studi Komunikasi Penyiaran Islam (KPI) memanfaatkan internet atau jejaring social media dalam menyapaikan dakwah sebagai memotivasi serta dalam mendukung perkuliahan mereka. sehinggapenulis memilih judul ini

\section{${ }^{4}$ Susilofy.}

Pengertian Landasan Psikologis dalam Pendidikan.http://susilofy.wordpress.com/ (Diakses tanggal 20 april 2015).

${ }^{5}$ Alvina, Gifta. Teori Usesand Gratifications.,

http://meopinion.wordpress.com/2010/09/27/teori-uses-and-gratifications/ (Diakses tanggal 20 april 2015). 
Derwin, Suharto, Syamsuri, Aksesibiitas Media Sosial Dakwah....

yaitu "Aksesibilitas Sosial Media Dakwah Mahasiswa Komunikasi Penyiaran Islam (KPI) IAIN Palu."

\section{B. Pengertian Aksesibilitas}

Kata aksesibilitas berasal dari bahasa Inggris (accessibility) yang artinya kurang lebih kemudahan .Jadi accessibility adalah hal yang mudah dicapai. Artinya aksesibilitas tidak hanya sekedar kesediaan segala sesuatu, namun juga kesediaan itu yang mudah dicapai. ${ }^{6}$

Internet adalah hubungan (koneksi) satu komputer ke komputer lainnya diseluruh dunia melalui server dan router terdedikasi.Ketika dua komputer terhubung lewat internet, mereka bisa saling kirim dan terima informasi seperti teks, grapik (gambar), suara, video dan program komputer berupa software dan aplikasi.Mengakses internet adalah sebuah kegiatan yg berkaitan dengan interaksi user dengan komputer yg terkoneksi dengan internet akses internet bisa menggunakan bermacam macam media computer pribadi, handphone, tv kabel, dan lain-lain. ${ }^{7}$

\section{Gambaran Umum Media Sosial}

Media telah menjadi sahabat manusia, tiada hari tanpa media. Melepaskan diri berarti menjadikan diri layaknya makhluk aliens ditengah makhluk informatif. Menyadari bahwa masyarakat tak dapat melepaskan diri, maka media pun bergerak melakukan akselerasi dari sisi kuantitas institusi dan ragam program tawaran hingga sisi kualitas bentuk dan pelayanan yang dapat memanjakan keinginan informatif manusia. 28 April 2015

${ }^{6}$ http://cahyageo.blogspot.com/2012/04/aksesibilitas.html Diakses pada tanggal

${ }^{7}$ http://nailauthar.blogspot.com/2012/10/pengertian-akses-internet diakses pada tanggal 28 April 2015 
New Media atau media baru disebut juga new media digital. Media digital adalah media yang kontennya berbentuk gabungan data, teks, suara, dan berbagai jenis yang yang disimpan dalam format digital dan disebarluaskan melalui jaringan berbasis kabel optic boarband satelit dan system gabungan mikro.

Ciri-ciri utama internet sebagia media adalah ${ }^{8}$ :

a. Tenologi berbasis computer

b. Karakteristiknya hibrida, tidak berdedikasi, fleksibel

c. Potensi interaktif

d. Fungsi balik dan privat

e. Peraturan yang tidak ketat

f. Kesalingterhubungan

g. Ada dimana-mana/tidak tergantung lokasi

h. Dapat diakses invidu sebagia komunikator

i. Media komunikasi massa dan pribadi

Melalui internet, surat kabar telah bisa diakases sebagai teks, danpengguna bisa menjelajah kabar tertentu dari belahan dunia secara cepat. Salah datu konten yang telah berkembang danmenjadi alasan menggunakan internet adalah adanya media social. Menurut Andreas Kaplan dan Michael Haenaen mendefenisikan social media sebagai berikut: "sebuah kelompok aplikasi berbasis internet yang membangun diatas ideology dan teknologi web dan yang memungkinkan penciptaan dan pertukaran user generated content'.

Sementara itu dari aspek kualitas, masyarakat pemirsa, pendengar dan pembaca telah dimanjakan dengan berbagai kemudahan pelayanan dan beragamnya acara menarik. Mulai dari kelas publik hingga privasi disediakan oleh media. Mulai dari hiburan keluarga hingga berita investigative. Mulai program acara produk local (dalam negeri), hingga

${ }^{8}$ Deddy Mulyana, Ilmu Komunikasi, Study Pengantar, (Bandung: Remaja Rosda Karya, 2001), h. 103 
Derwin, Suharto, Syamsuri, Aksesibiitas Media Sosial Dakwah....

internasional. Pendek kata, semua telah tersedia komplit. Belum lagi kualitas fisikal media (gambar dan bentuk) begitu luar biasa, terlebih di dunia pertelevisian, teknologi digital telah memberikan sentuhan kekuatan vision yang luar biasa. Kesemua tawaran media kepada khalayak bukanlah isapan jempol. Tebukti survey Nielsen Indonesia yang dirilis tanggal 6 maret 2013 dengan tajuk "Uncommon Sense of the Consumer" menunjukan peningkatan signifikan konsumsi media oleh masyarakat media. $^{9}$

Beragamnya jenis media dan program yang ditawarkan yang diikuti oleh keinginan menggebu penikmat media ini tentunya harus diwaspadai, mengingat informasi yang disajikan media adalah informasi yang dikontruksi yang kebenarannya belum tentu mutlak.Beragamnya pesan-pesan yang disampaikan media sesungguhnya lebih dari sekedar merefleksikan realitas tapi juga merepresentasikan realitas, sehingga sangat dimungkinkan terjadi penyederhanaan realitas dan justifikasi representatif.

Tidak mengherankan jika dalam berbagai riset media ataupun komunikasi massa sering ditemukan berbagai pengaruh negative dari media. Meski temuan tersebut menimbulkan pro dan kontra, namun berbagai pakar media mengakui pengaruh media begitu signifikan terhadap perubahan perilaku khalayak media.Kondisi ini jelas mengkhawatirkan, terlebih lagi jika khalayak media, bukan terkategori khalayak aktif, tapi khalayak pasif yang tidak memiliki keberdayaan dalam melihat isi media secara kritis dan cerdas.Akibatnya mereka menjadi

${ }^{9}$ Kris Moerwanto, "Anomali Daya Tahan Media Tradisional" dalam Jawa Pos : Rabu 13 Maret 2012 
terhegemoni oleh media.Apa yang dikatakan media dianggap sebagai kebenaran, apa yang disajikan media itu realitas sesungguhnya.

\section{Manfaat Media Sosial}

\section{Sebagai Media Alat Komunikasi}

Banyak pendapat yang mendefinisikan tentang apa itu komunikasi. Diantaranya adalah William Albig medefinisikan "komunikasi adalah sebagai proses pengoperan lambang-lambang yang berarti diantara individu-individu yang lain (komunikan)". ${ }^{10}$

Dari pengertian diatas, dapat dipahami bahwa komunikasi merupakan penyampaian pesan dari seorang komunikator kepada komunikan dengan melalui media tertentu. Salah satunya media social merupakan fitur yang berbasis website yang dapat membentuk jaringan serta memungkinkan orang untuk berinteraksi dalam sebuah komunitas. Pada media sosial kita dapat melakukan berbagai bentuk pertukaran, kolaborasi dan saling berkenalan dalam bentuk tulisan visual maupun audiovisual. ${ }^{11}$

Di era yang semakin canggih ini, berkomunikasi tak perlu lagi menggunakan surat, melainkan menggunakan fasilitas digital yang tersedia saat ini, seperti halnya di internet. Internet mampu berperan sebagai media komunikasi kita dengan orang lain. Terlepas dari persoalan tersebut, kehadiran teknologi informasi dan komunikasi telah mendinamisasi kehidupan manusia. Penggunaannya semakin meningkat dari waktu ke waktu, terlebih dengan hadirnya media baru yang mampu h. 7

${ }^{10}$ M. Kholili, Komunikasi Untuk Dakwah, (Yogyakarta, UIN Sunan Kalijaga, 2008),

${ }^{11}$ Puntoadi, Danis. Menciptakan Penjualan Melalui Media Sosial, ( :2011), h. 1 
Derwin, Suharto, Syamsuri, Aksesibiitas Media Sosial Dakwah....

mengumpulkan, memproses dan mempertukarkan informasi secara cepat. Ini berarti kemampuan berinteraksi manusia satu dengan manusia lainnya melalui instrument yang bernama teknologi informasi dan komunikasi telah mengubah pola berkomunikasi manusia secara fundamental (mass self communications). Perubahan pola komunikasi itu, jelas tak bisa dilepaskan dari sifat "alamiah" teknologi informasi dan komunikasi. Ketika ia hadir, ketika itu pula ia akan mengubah pola kehidupan manusia, termasuk pola berkomunikasinya.

\section{Sebagai Media Pendukung Perkuliahan}

Kata media berasal dari bahasa latin, Median, yang merupakan bentuk jamak dari medium. Secara etimologi alat atau perantara. Seiring dengan pesatnya perkembangan sains dan teknologi, problematika dakwah Islam semakin kompleks. Baik di bidang sosial, ekonomi, budaya, politik dan sebagainya. Kemajuan teknologi informasi dapat dijadikan penyebaran dakwah Islamiyah, khususnya teknologi informasi seperti internet.

Denis McQuail mendefenisikan media sebagai berikut :

"Media sebagai teknologi informasi yang dapat digunakan dalam pengajaran. Secara lebih spesifik, yang dimaksut dengan alatalatmedia adalah alat-alat fisik yang menjelaskan isi pesan atau pengajaran, seperti buku, film, video kaset, slide,dan sebagainya". ${ }^{12}$

Penggunaan internet untuk keperluan pendidikan yang semakin meluas terutama dinegara-negara maju, merupakan fakta yang menunjukan bahwa dengan media ini memang dimungkinkan

${ }^{12}$ McQuail, Denis .Teori Komunikasi Massa, (Jakarta : Erlangga, 1991), h. 71 
diselenggarakannya proses belajar mengajar yang lebih efektif. Hal ini terjadi karena dengan sifat dan karakteristik internet yang cukup luas. Sehingga diharapkan bisa digunakan sebagai media pembelajaran sebagaimana media lain yang telah dipergunakan sebelumnya. Seperti radio, televisi, $\mathrm{CD}-\mathrm{ROOM}$ interaktif dan lain-lain.

Sebagai media yang diharapkan akan menjadi bagian dari suatu proses belajar mengajar di perguruan tinggi, internet harus mampu memberikan dukungan bagi terselenggaranya proses komunikasi interaktif antara dosen dengan mahasiswa sebagaimana dipersyaratkan dalam suatu kegiatan pembelajaran. Kondisi yang harus mampu didukung oleh internet tersebut terutama berkaitan dengan strategi pembelajaran yang akan dikembangkan, yang jika dijabarkan secara sederhana, bisa diartikan sebagai kegiatan komunikasi yang dilakukan untuk mengajak mahasiswa untuk mengerjakan tugas-tugas dan membantu mahasiswa dalam memperoleh pengetahuan yang dibutuhkan dalam rangka mengerjakan tugas-tugas tersebut.

Strategi pembelajaran meliputi pengajaran, diskusi, membaca, penugasan, presentasi dan evaluasi, secara umum keterlakasanaanya tergantung dari satu atau lebih dari tiga mode dasar dialog/komunikasi sebagai berikut ;

- Dialog/komunikasi antara dosen dan mahasiswa

- Dialog/ komunikasi antara mahasiswa dengan sumber belajar

- Dialog/ komunikasi di antara mahasiswa 
Derwin, Suharto, Syamsuri, Aksesibiitas Media Sosial Dakwah....

Apabila ketiga aspek tersebut bisa diselenggarakan dengan komposisi yang serasi, maka diharapkan akan terjadi proses pembelajaran yang optimal. ${ }^{13}$

Dengan demikian terlihat bahwa secara nyata internet memang akan bisa digunakan dalam mendukung perkuliahan diperguruan tinggi, karena memiliki karakteristik yang khas yaitu:

1. Sebagai media interpersonal dan juga sebagai media massa yang memungkinkan terjadinya komunikasi one-to-one maupun one-tomany.

2. Memiliki sifat interaktif.

3. Memungkinkan terjadinya komunikasi secara sinkron (synchronous) maupun tertunda (asynchronous), sehingga memungkinkan terselenggaranya suatu proses belajar mengajar. ${ }^{14}$

Pengaruh teknologi dalam pendidikan memunculkan sejumlah besar sumber belajar yang tersedia bagi mahasiswa. Fenomena ini menunjukan bahwa dosen bukan lagi menjadi satu-satunya sumber informasi. Maka suatu tipe pendidikan yang lebih luwes dibutuhkan bagi mahasiswa untuk mengembangkan diri mereka sendiri secara maksimal dengan menggunakan semua sumber dapat merencanakan sendiri target belajarnya, melalui revisi atau balik lagi kepada materi sebanyak yang dibutuhkan. Hal ini merupakan fakta bahwa mahasiswa mempunyai

13 Bradley, Phil. The Advanced Internet Searcher's Handbook. London: library association Publishing 1999.

${ }^{14}$ Hardjito. Internet Untuk Pembelajaran 2015.

.http://www.pustekom.go.id/teknodik/t10/10-3.htm . Diakses pada tanggal 5 Mei 
control lebih besar atas cara mereka belajar, dengan dosen memainkan peran sebagai fasilitator proses belajar. ${ }^{15}$

\section{Media Sebagai Strategi Dakwah}

Strategi dapat berarti ilmu siasat perang, muslihat untuk mencapai sesuatu. ${ }^{16}$ Secara etimologi, kata dakwah berasal dari bahasa arab da'wah yang merupakan bentuk mashdar dari kata kerja (fi'il) da'a yad'u yang artinya seruan, ajakan, panggilan. Sedangkan bentuk kata kerja (fi'il) berarti memanggil, menyeru atau mengajak (da'a, yad'u, da'watan). Orang yang berdakwah bisa disebut dengan da'i dan orang yang menerima dakwah atau orang yang didakwahi disebut dengan mad'u. ${ }^{17}$ Secara terminologis banyak yang berpendapat para ahli dakwah tentang defenisi dakwah. Dakwah adalah suatu proses mengajak, mendorong (memotivasi) manusia untuk berbuat baik, mengikuti petunjuk Allah swt, menyuruh mengerjakan kebaikan, melarang mengerjakan kejelekan, agar dia bahagia dunia dan akhirat. ${ }^{18}$

Sementara itu Abdul Munir Mulkhan mengartikan dakwah sebagai usaha mengubah situasi kepada yang lebih baik dan sempurna, baik terhadap individu maupun masyarakat. Secara konseptual, dakwah dipahami oleh para pakar secara beragam. Ibnu Tamiyyah misalnya,

\footnotetext{
${ }^{15}$ Diptoadi, Veronica L, Susanto Teopilus dan Hartono Pranyoto. Kontribusi Teknologi Informasi dan Komunikasi dalam Memperbaiki Pengaksesan PBTJJ : Sebuah Studi Kasus.http://www.Pustekom.go.id/teknodik/t10/10-10.htm. Diakses pada tanggal 7 Mei 2015

${ }^{16}$ M. Dahlan Al Barry, Kamus Ilmiah Populer, (Surabaya : Arkola, tt), h. 448

${ }^{17}$ Munawir, Ahmad Warson. Kamus Al-Munawwir. (Surabaya :Pustaka Progresif,1997), h. 406-407

${ }^{18}$ Saerozi, Ilmu Dakwah, (Yogyakarta :penerbit ombak, 2013), h. 10
} 
Derwin, Suharto, Syamsuri, Aksesibiitas Media Sosial Dakwah....

mengartikan dakwah sebagai proses usaha untuk mengajak masyarakat (mad'u) untuk beriman kepada Allah dan Rasul-Nya sekaligus mentaati apa yang diperintahkan oleh Allah dan Rasul-Nya itu. ${ }^{19}$

Diatas telah diuraikan bahwasanya kata media barasal dari bahasa latin, Median yang secara etimologi diartikan sebagai alat perantara. Adapun yang dimaksut dengan media (wasilah) dakwah yaitu alat yang dipergunakan untuk menyampaikan materi dakwah (ajaran Islam) kepada mad'u dengan banyaknya media yang ada, maka da'i harus memilih media yang paling efektif untuk mencapai tujuan dakwah. ${ }^{20}$

Srtategi yang dilakukan dalam kegiatan membangun jaringan dakwah adalah dengan memanfaatkan perkembangan global connection.System ini merupakan salah satu alternatif untuk dijadikan sebagai media berdakwah. Aspek keuntungan yang diperoleh dengan pemanfaatan jaringan internet (dalam hal ini adalah media sosial) ini antara lain dapat mempererat jalinan persaudaraan antara satu dengan lainnya juga dapat memberikan informasi dalam waktu yang singkat (aspek sosial), dapat berdiskusi mengenai perkembangan Islam (aspek agama) serta membangun Ilmu Pengetahuan Teknologi (aspek ilmu pengetahuan).

Fenomena dakwah melalui media social khususnya di Indonesia mengalami perkemnbangan yang cukup pesat. Hal ini ditandai dengan hadirnya para aktivis dakwah untuk memanfaatkan media social sebagai sarana media Islam, yang tujuannya tidak lain untuk menambah wawasan

\footnotetext{
${ }^{19}$ McQuail, Denis. Teori Komunikasi..., h. 7

${ }^{20}$ Ilaihi, Wahyu, Komunikasi Dakwah. (Bandung : Remaja Rosdakarya. 2010), h.
} 70 
keilmuan dan informasi seputar dunia Islam. Adapun alasan penggunanya memilih media social karena :

a. Media sosial merupakan situs yang paling banyak diakses oleh manusia diseluruh belahan dunia. Hal ini memberikan peluang besar bagi pendakwah untuk dapat memanfaatkan media social sebagai media dakwah Islam.

b. Dakwah melalui internet dapat memudahkan untuk memilih materi dakwah yang mereka sukai, dengan demikian pemaksaan kehendak dapat dihindari. ${ }^{21}$

Alasan-alasan tersebut sidah cukup menjadi bukti, bahwa media social sangan efektif dalam proses penyampaian dakwah. Terutama dizaman berteknologi canggih seperti ini. Menyampaikan kebenaran ajaran-ajaran Islam kepada umat manusia merupakan tanggung jawab kita yang telag menerima dan memeluk ajaran Islam, umat Islam mempunyai kewajiban untuk menyampaikan kebenaran Islam dengan wajah yang menarik lagi mempesona, sesuai dengan misinya Rahmatan Lil' Alamin. ${ }^{22}$

\section{E. Internet Sebagai Media Dakwah}

Sejauh ini, semakin banyaknya pengguna internet terutama dalam beberapa tahun belakangan ini, di kalangan akademisi telah memanfaatkan sarana internet secara optimal bagi pengembangan syiar agama. Hal tersebut ditandai dengan banyak bermunculan situs baru bernuansakan Islam. Sebab itu, bisa dikatakan dakwah melalui internet ini

\footnotetext{
${ }^{21}$ http://Blogfajri.wordpress.com.Di akses pada tanggal 05 mei 2015, jam 10.15

${ }^{22}$ Munzeir Suparna, Metode Dakwah, (Jakarta : Kencana, 2003), h. 65
} 
Derwin, Suharto, Syamsuri, Aksesibiitas Media Sosial Dakwah....

sangat efektif karena didukung oleh sifat internet yang tidak terbatas ruang dan waktu. Materi ke-Islaman dan dakwah bisa disebarkan dengan cepat dan efisien. Informasi yang disebarkan lewat internet, dapat menjangkau siapapun dan di manapun asalkan yang bersangkutan mengakses internet. Sejatinya, tak hanya konsep dakwah konvensional yang dapat diberikan melalui internet.Umat Islam bisa memanfaatkan teknologi itu untuk kepentingan bisnis Islami, silaturahmi dan lain-lain.

Perintah menjalankan dakwah sebenarnya sudah dijelaskan Allah SWT., dalam kitab suci Alquran.Diantaranya :

a. QS Al Imran (3) ayat 104;

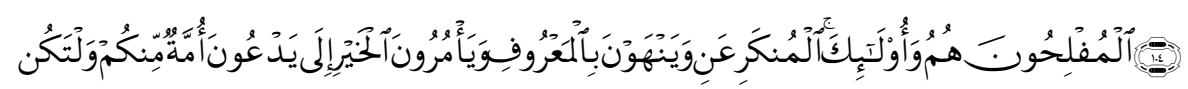

Terjemahan :

"Dan hendaklah di antara kamu ada segolongan orang yang menyeruh kepada kebajikan, menyuruh (berbuat) yang makruf, dan mencegah dari yang mungkar.Dan merekaitulah orang-orang yang beruntung". ${ }^{23}$

Maksud ma`ruf di sini ialah segala perbuatan yang mendekatkan diri pada Allah sedang munkar ialah segala perbuatan yang menjauhkan diri dari Allah.

b. QS Al- An'am (6) ayat 153;

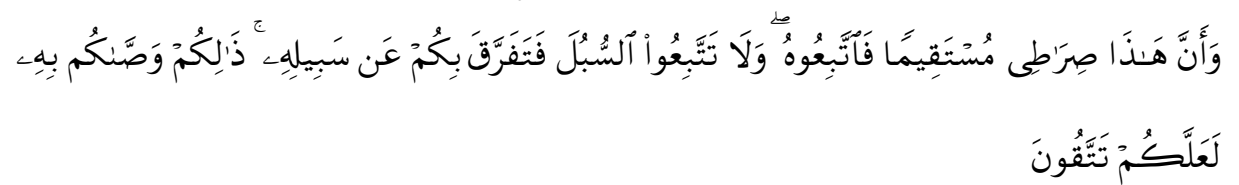

23 Departemen Agama RI, Al-Qur'an dan Terjemahan, (CV. Pustaka Agung Harapan: 2006), h. 79 
Terjemahan :

"Dan bahwa (yang Kami perintahkan ini) adalah jalanKu yang lurus, Maka ikutilah Dia, dan janganlah kamu mengikuti jalanjalan (yang lain)[152], karena jalan-jalan itu mencerai beraikan kamu dari jalanNya. yang demikian itu diperintahkan Allah agar kamu bertakwa". ${ }^{24}$

Di samping perintah Allah SWT. Nabi Muhammad SAW. juga bersabda kepada ummatnya: "Sampaikanlah walau hanya satu ayat". Sabda Nabi ini memiliki makna bahwa seluruh umat Islam senantiasa harus menyampaikan ilmu yang di milikinya kepada orang lain, kapanpun, di manapun mereka berada. Hal ini sebagai tanggung jawab pribadi muslim dalam menjalani kehidupan di muka bumi ini.

Semangat dakwah yang ditegaskan Nabi Muhammad SAW diatas; meskipun hanya satu ayat, merupakan satu bentuk "tanggung jawab moral" yang sangat mengakar di kalangan umat Islam.Segala daya dan upaya untuk melakukan dakwah terus dilakukan, hingga kini.Setelah beratus tahun berselang sejak dakwah lisan dikumandangkan oleh Rasulullah, pada masa kini dakwah telah menggunakan media digital. Dakwah dalam bentuk tulisan di buku, koran, majalah, tv dan radio mendapatkan komplementernya berupa text dan di internet.

Dakwah dapat berjalan secara efektif dan efesien apabila terlebih dahulu menidentifikasi dan mengantisipasi masalah-masalah yang muncul dan bakal muncul dan dilengkapi dengan pengenalan objek yang lebih tepat. Untuk menyampaikan pesan dakwah, seorangjuruh dakwah (da'i)

${ }^{24}$ Ibid, h. 200 
Derwin, Suharto, Syamsuri, Aksesibiitas Media Sosial Dakwah....

dapat menggunakan berbagai macam media dakwah, baik itu media modern (alat elektronika) maupun media tradisional. ${ }^{25}$

Dengan demikian internet merupkan salah media yang sangat tepat untuk dijadikan sarana/media dalam berdakwah. Karena saat ini internet merupakan media dan sumber informasi yang paling canggih. Karena teknologi ini menawarkan berbagai kemudahan, kecepatan, ketepatan akses dan kemampuan menyediakan berbagai kebutuhan informasi setiap orang, kapan saja, dimana saja dan pada tingkat apa saja. Berbagai informasi yang dapat diperoleh melalui Internet antara lain lapangan pekerjaan, olahraga, seni, belanja, perjalanan, kesehatan, permainan, berita, komunikasi lewat email, mailing list, dan chatting, bahkan artikel-artikel ilmiah dalam berbagai disiplin ilmu, dan lain sebagainya. Hampir semua bidang tugas manusia, apapun jenisnya, dapat dicari melalui Internet.Internet sebagai sumber informasi memungkinkan semua orang untuk terus belajar seumur hidup, kapan dan dimanapun serta untuk keperluan apapun.Dan untuk kebutuhan belajar bagi setiap individu, Internet tidak hanya menyediakan fasilitas penelusuran informasi tetapi juga komunikasi.

Matthew DeBell dari The Education Statistics Services Institute (ESSI) mengatakan bahwa:

"Penggunaan komputer dan Internet dapat meningkatkan kualitas hidup orang setiap hari dan meningkatkan prospek pasar kerja mereka. Karena teknologi ini mempunyai potensi meningkatkan

${ }^{25}$ Mahmudin, Manajemen Dakwah Rasulullah SAW, (Jakarta : Restu Ilahi, 2004), h. 7 


\section{$\Delta L-n i 5 H 3 d$, Volume 12 Nomor 2 Juli-Desember 2016: 183-210}

akses kepada informasi, membantu menyelesaikan tugas lebih baik dan lebih cepat, dan sebagai media komunikasi" ${ }^{26}$

Tingkat penggunaan komputer dan internet dapat dianggap sebagai indikator standar hidup. Di samping itu, penggunaan komputer juga akan membantu para pelajar memperoleh pengalaman dengan teknologi ini, dengan demikian tingkat penggunaan bisa mengindikasikan sejauh mana generasi pelajar sekarang siap untuk memasuki lapangan kerja di mana kemampuan untuk menggunakan komputer sangat dibutuhkan.

Dari uraian diatas telah disebutkan bahwa penggunaan internet sebagai media untuk dakwah itu di bolehkan. Karena dengan melalui internet upaya dalam berdakwah dapat diakses ke berbagai media, sehingga dapat dilihat oleh seluruh kalangan di seluruh pengguna internet.Dan akan mempermudah bagi juru dakwah untuk menyampaikan dakwah dan juga agar mudah dipahami oleh sasaran dakwah (mad'u), maka sebaiknya dakwah dilakukan dengan menggunakan salah satu media yang ada. Hal ini untuk menyesuaikan keadaan masyarakat yang tidak sama, di satu sisi sudah modern, di sisi lain masih tradisional. ${ }^{27}$

\footnotetext{
${ }^{26} \mathrm{http}$ ://burhanuddin-13.blogspot.com/2010/06/pemanfaatan-internet-untukkemajuan-html diakses pada tanggal 29 Aplril 2015 jam 11.36

${ }^{27}$ Baroroh, Umul dkk.Efek Berdakwah Melalui Media Tradisional, IAIN Walisongo, Semarang, 2009, h. 1- 4
} 
Derwin, Suharto, Syamsuri, Aksesibiitas Media Sosial Dakwah....

\section{F. Aksesibilitas Media Sosial Dakwah Mahasiswa KPI di IAIN Palu.}

Pada penelitian ini, informan yang dipilih adalah mahasiswa Komunikasi Penyiaran Islam (KPI) IAIN Palu yang berjumlah 9 orang. Alasan pemilihan informan didasarkan akan kebutuhan data dan informasi tentang jejaring social media. Karena seluruh informan telah menggunakan internet. Artinya semua informan pernah menggunakan social media untuk memenuhi kebutuhan informasi.

a). Manfaat Social Media bagi mahasiswa Komunikasi Penyiaran Islam (KPI) dalam mengakses Perkembangan dakwah.

Di abad 21 ini media internet sudah tidak asing lagi. Media ini dirasakan sangat bermanfaat untuk pemenuhan kebutuhan komunikasi dan memperoleh informasi sekaligus materi kuliah. Apalagi sejak kemunculan media jejaring sosial, intensitas penggunaan internet semakin meningkat. Ada beberapa tujuan mahasiswa KPI mengakses media sosial dakwah, yakni;

1) Menjalin Silaturrahim

Media sosial menjadi media yang sangat diminati mahasiswa saat ini, khususnya dalam menjalin silaturrahim dengan teman-teman yang lain dan mendapatkan teman-teman baru. Tidak hanya teman sederajat tetapi juga dosen dan kalangan lain tanpa dibatasi usia dan jenis kelamin, etnis, agama dan ras tertentu. Silaturrahim itu dibangun juga melalui grup-grup facebook dikalangan mahasiswa maupum dengan pengguna masyarakat umum. 
2). Mengakses informasi Islam

Melalui media sosial, mahasiswa KPI dapat memperoleh informasi sebanyak-banyaknya, baik melalui teman media (facebook misalnya) maupun berita ditampilkan media yang menggunakan media sosial facebook, twitter dan lainnya. Sehingga dengan sendirinya mahasiswa pengguna media sosial diuntungkan dalam menangkap percepatan penyampaian informasi tersebut. Informasi-informasi ini juga beragam. Baik informasi yang bersifat umum, maupun informasi tentang agama Islam. Informasi-informasi yang berkaitan dengan agama Islam itulah disebut penyampaian dakwah dan pengguna media dalam hal ini mahasiswa KPI sebagai audience atau mad'u atau penerima dakwah.

3). Mengakses Informasi untuk Menyelesaikan Tugas-tugas Kuliah

Media sosial pada prinsipnya hanyalah media informasi dan menghubungkan orang-orang yang ingin menjalin silaturrahim, media sosial juga dapat digunakan oleh pribadi-pribadi yang ingin menekspos pikiran atau gagasan-gagasan singkatnya yang bermanfaat bagi orang lain. baik yang sebelumnya dimuat dalam blog maupun website dan kemudian ditaut ke facebook atau twiteer maupun diupload atau diposting secara langsung. Mahasiswa dapat memanfaatkan informasi gagasan tersebut sebagai bahan memenuhi tugas-tugas kuliah, tentu selain membuka langsung ke google dan wikipedia atau yang lainnya.

4). Meng-upload informasi

Selain memanfaatkan media sosial untuk mengaskses informasi dan bahan memenuhi tugas-tugas kuliah, mahasiswa KPI mengguakan media sosial untuk melakukan kegiatan interpreneurship. 
Derwin, Suharto, Syamsuri, Aksesibiitas Media Sosial Dakwah....

Mensosialisasikan diri, gagasan, karya dan kegiatan-kegiatan yang positif yang dapat menjadi contoh dan motivasi bagi orang lain. Termasuk membuat bloq dan mengisinya dengan informasi-informasi Islam sejauh pengetahuan mahasiswa, yang paling penting bagi mahasiswa adalah dapat belajar memanfaatkan media sosial dengan hal-hal yang bersifat interpreneurship dan dengan demikin diharapkan mengandung unsur dakwah, atau usaha-usaha yang positif untuk merubah diri.

5). Lahan Bisnis online

Media sosial dapat menjadi lahan bisnis yang efektif dan efisien. Beberapa mahasiswa menggunakannya sebagai media untuk mempromosikan barang-barang bisnis seperti kue atau makanan khas Sulawesi.

b). Alasan Mahasiswa Komunikasi Penyiaran Islam (KPI) IAIN Palu memilih Media Social sebagai Media Dakwah.

Berikut beberapa alasan yang di ungkapkan mahasiswa mengapa lebih memilih media social sebagai media dakwah, Antara lain;

1). Aplikasinya mudah diakses dan digunakan

Ada beberapa jenis aplikasi media sosial yang digunakan oleh mahasiswa KPI, seperti aplikasi facebook, twiteer, instagram, line, whatsapp (WA), BBM, peth, youtube, hi5, Linkedin, mailing list dan blog. Saat membeli handphon/android pun aplikasi-aplikasi ini sudah tersedia di counter-counter handphone diisi dengan lengkap oleh pelayannya. Dalam penggunaannya pun aplikasi-aplikasi ini sangat mudah.

Dari semua jenis aplikasi media sosial ini yang paling banyak digunakan oleh mahasiswa KPI adalah facebook, WA, mailing list dan blog. Alasannya karena facebook, mailing list dan WA cukup banyak pengguna 
dari kalangan mahasiswa KPI dan keluarga sehingga memudahkan mereka berinteraksi. Mailing list digunakan untuk kepentingan pengiriman file dan surat kepada dosen maupun kawan-kawan sekaligus menjaga agar file-file tetap tersimpan dengan baik di inbox mail atau surat mausk dan surat keluar. Bolg menjadi media mahasiswa belajar menuangkan gagasan dan sosialisasi informasi Islam atau dakwah.

2. Kontennya simple dan ekonomis

Tidak dipungkiri, bahwa beberapa jenis aplikasi media sosial diminati oleh masyarakat khususnya mahasiswa karena kontennya yang simpel, mudah digunakan, efektif dan efisien. WA misalnya sudah bisa digunakan untuk dialog secara langsung siapapun sesama penggunan WA, juga ekonomis. Jika pulsa habis namun paketan masih ada, mahasiswa suda bisa berkomunikasi dengan relasinya.

c). Prospek Penggunaan Sosial Media Dikalangan Mahasiswa Komunikasi Penyiaran Islam (KPI) IAIN Palu

Informasi yang di peroleh dilapangan memberikan indikasi bahwa prospek penggunaan media social oleh mahasiswa Komunikasi Penyiaran Islam (KPI) di IAIN Palu cukup beragam. Karena diantaranya memiliki pendapat masing-masig tentang penggunaan media social, bahkan sudah menjadi sesuatu yang tidak terpisahkan atara satu dengan yang lain. Pengguna yakni mahasiswa Komunikasi Penyiaran Islam (KPI) IAIN Palu. Saat diwawancara memberikan pendapat sehingga mereka yakin prospek media sosial dakwah sangat baik dengan alasan sebagi berikut;

- Kebutuhan akan penggunana media social itu cukup banyak sehingga media social merupakan salah satu media alternatif yang efektif untuk digunakan. 
Derwin, Suharto, Syamsuri, Aksesibiitas Media Sosial Dakwah....

- Media social selain dapat digunakan untuk mendapatkan informasi juga dapat dijadikan penyambung silaturrohim terhadap sesama.

- Dengan media sosial semua dapat dilakukan seperti : berbelanja (online), menjalankan bisnis, pertemanan dan juga sebagai sarana hiburan (games).

d). Kendala yang sering dialami oleh Pengguna Media Sosial dalam mengakses informasi

Dalam penggunaan jaringan komputer, sering kali terjadi masalah yang menjengkelkan, misalnya internet lelet, tidak bisa konek, dan lainlain.Masalah seperti ini sering terjadi pada sebuah jaringan komputer.Dan berikut adalah masalah-masalah yang sering terjadi pada sebuah jaringan komputer.

Berdasarkan data yang diperoleh dari lapangan melalui hasil wawancara terhadap informan, bahwa dalam mengakses internet itu terdapat beberapa kendala atau hambatan sekalipun tidak semua informan mengakuinya. Identifikasi penulis mengenai hambatan yang dimaksut pengguna internet atau media sosial lainnya adalah sebagai berikut :

a) Lambatnya Koneksi Internet, Koneksi wireless melemah ataupun tidak memberikan hasil yang maksimal dapat diakibatkan karena peranggkat access point yang bermasalah ataupun instalasi wireless yang bermasalah.

b) Kerusakan Jaringan Karena Serangan Virus, ini juga merupakan masalah jaringan yang bukan karena kegagalan infrastruktur jaringan fisik, akan tetapi system jaringan anda akan kebanjiran 


\section{$\Delta L-n i 5 H 3 d$, Volume 12 Nomor 2 Juli-Desember 2016: 183-210}

traffic dari pengaruh virus yang menyerang system server dan menulari ke semua komputer dalam jaringan.

c) Koneksi yang putus nyambung, mungkin juga menjadi salah satu penyebab mengapa internet Anda menjadi lemot. Untuk mengatasi masalah ini, coba lakukan refresh. Utilitas ini digunakan untuk mengecek koneksi.

d) Terlalu banyak pemakaian, karena banyaknya pemakaian sehingga menyebabkan lambatnya jaringan/koneksi internet. Hal ini dilihat dari banyaknya kebutuhan mahasiswa terhadap pemakaian jaringan internet, baik mereka yang menggunakan jaringan internet untuk mengakses Informasi dari sosial media, maupun media laiinya untuk menunjang materi perkuliahan atau tugas-tugas perkuliahan yang diberikan oleh dosen.

\section{G. Penutup}

Jejaring sosial atau media sosial kini menjadi trend bagi masyarakat luas, khususnya mahasiswa. Bahkan media jejaring sosial bisa dikatakan sebagai media komunikasi terfavorit di kalangan mahasiswa. Tidak jarang mahasiswa yang menganggap aktivitas berjejaring sosial merupakan gaya hidupnya. Media sosial ini layaknya candu yang membuat para mahasiswa ketagihan. Banyak pula mahasiswa yang menganggap situs jejaring sosial sebagai sahabatnya.

Pengguna jejaring sosial pun semakin bertambah. Kemudahan dalam mengoperasikan dan mengakses, biaya akses yang murah, hadirnya aplikasi-aplikasi yang menarik, serta pengembanganpengembangan yang dilakukan provider ikut ambil bagian dalam peningkatan jumlah pengguna jejaring sosial ini. 
Derwin, Suharto, Syamsuri, Aksesibiitas Media Sosial Dakwah....

Para mahasiswa mengaku, banyak sekali manfaat yang mereka dapat di jejaring sosial. Sebagian besar mengungkapkan bahwa jejaring sosial :

a). Merupakan media komunikasi yang efektif. Tentu saja hal itu dikarenakan mayoritas mahasiswa mempunyai akun jejaring sosial dan aktif dalam mengaksesnya. Mereka dapat saling bertukar informasi dalam bidang akademik dan lain sebagainya.

b). Sebagai hiburan yang murah meriah disaat kita lelah dengan tugastugas yang menumpuk. Kita dapat sejenak bermain di dunia maya untuk curhat atau lain sebagainya.

c) memperkuat hubungan pertemanan, membangun hubungan sosial dalam dunia maya, menghapus batasan teman dalam dunia nyata, mengikuti trend teman sebaya, berbagi foto, berhubungan dengan teman lama, dan lain sebagainya.

d) Kewirausahaan, media jejaring sosial dapat dimanfaatkan sebagai ajang promosi. Mereka melakukan branding lewat situs-situs jejaring sosial tersebut. Hal tersebut dirasa mudah dengan hadirnya fasilitasfasilitas untuk mengunggah foto, video dan lain sebagainya. Selain mudah, promosi ini juga efektif dan tidak memerlukan biaya. Jadi bisa disimpulkan bahwa media jejaring sosial membawa banyak manfaat dan kemudahan bagi mahasiswa.

\section{Daftar Pustaka}

Departemen Agama RI, Alquran danTerjemahan, CV. Pustaka Agung Harapan: 2006)

A. Ridwan Siregar, Panduan Perpustakaan Universitas, Medan: Perpustakaan USU, 2001

Ahmad WarsonMunawir, Kamus Al-Munawwir. Surabaya: Pustaka Progresif,1997 


\section{$\Delta$ L-nis H $3 \pm$ H}

Baroroh, Umuldkk. Efek Berdakwah Melalui Media Tradisional, IAIN Walisongo, Semarang, 2009

McQuailDenis,.Teori Komunikasi Massa SuatuPengantar, Jakarta :Penerbit Erlangga, 1987

Danis, Puntoadi. Menciptakan Penjualan Melalui Media Sosial, 2011

Kris Moerwanto, "Anomali DayaTahan Media Tradisional" dalam JawaPos

M. Dahlan Al Barry, Kamus Ilmiah Populer, Surabaya :Arkola, tt.

M. kholili, Komunikasi Untuk Dakwah, Yogyakarta, UIN SunanKalijaga, 2008.

Munzeir Suparna, Metode Dakwah, Jakarta :Kencana, 2003.

Mahmudin, Manajemen Dakwah Rosulullah, Jakarta : Restullahi, 2004

Phil Bradley,.The Advanced Internet Searcher's Handbook.London: library association Publishing 1999

Wahyu, Ilaihi, Komunikasi Dakwah. Bandung : Remaja Rosdakarya. 2010

Saerozi, Ilmu Dakwah, Yogyakarta :penerbit ombak, 2013.

Abu Ahmadi Chalid Nurboku, Metodologi Penelitian, cet 1, Jakarta : Bumi Aksara, 2002.

Arikunto Suharsimi, Prosedur Penelitian Suatu Pendekatan Praktek, Jakarta : BinaAksara 1989.

Dadang Kahmad, Metodologi Penelitian Agama, Cet I, Bandung ;PustakaSetia, 2000,

Joko P. Subagyo, metode Penelitian dalam Teori dan Praktek, Jakarta: Rineka Cipta, 1997

Kontjaraningrat, Metode PenelitianMasyarakat, Jakarta : PT. Gramedia, 1983.

SutrisniHadi, Metodologi Research, Yogyakarta : Andi Offset, 1992

Sumardi Surya Brata, Metodologi Penelitian, Cet. II, Jakarta : Raja Grafindo, 1998.

S. Nasution, Metode Reseacrh, (Penelitian Ilmiah), CV, Jakarta :Bumi askara, 2002.

Danah, Boyd, M Nicole B. Ellison. 2007. Social Network Sites :Definition, History,

Scholarship 
Derwin, Suharto, Syamsuri, Aksesibiitas Media Sosial Dakwah....

.http://jcmc.indiana.edu/vol13/issue1/boyd.ellison .html Diaksestanggal 20 April 2015).

Diptoadi, Veronica L, SusantoTeopilusdan Hartono Pranyoto. Kontribusi Teknologi Informasi dan Komunikasi dalam Memperbaiki Pengaksesan PBTJJ: Sebuah-Studi-Kasus http://www.Pustekom.go.id/teknodik/t10/10-10.htm. Diakses pada tanggal 7 Mei 2015

Gifta, Alvina. Teori Uses and Gratifications.

http://meopinion.wordpress.com/2010/09/27/teoriuses and gratification. (Diakses tanggal 20 april 2015)

Hardjito. Internet UntukPembelajaran.

http://www.pustekom.go.id/teknodik/t10/10-3.htm. Diaksespadatanggal 5 Mei 2015

Susilofy.

PengertianLandasanPsikologidalam Pendidikan.http://susilofy.wordpress.c om/ (Diaksestanggal 20 april 2015).

http://neysya-jatidiri.blogspot.com/2012/06/facebook-sebagai-media dakwah.html diakses pada tanggal 28 april 2015 jam 10.04

http://cahyageo.blogspot.com/2012/04/aksesibilitas.htmlDiaksespadatangg al 28 April2015

http://cahyageo.blogspot.com/2012/04/aksesibilitas.htmlDiaksespadatangg al 28 April 2015

http://nailauthar.blogspot.com/2012/10/pengertian-aksesinternetdiaksespadatanggal 28 April 2015

http://Blogfajri.wordpress.com. Di aksespadatanggal 05mei 2015, jam 10.15

http://burhanuddin-13.blogspot.com/2010/06/pemanfaatan-internet-untuk kemajuan html diakses pada tanggal 29 Aplril 2015 jam 11.36 